\title{
Variables associated with a pentobarbital-induced sleep response'
}

\author{
ROBERT A. LEVITT, UNIVERSITY OF PITTSBURGH \\ WILSE B. WEBB, UNIVERSITY OF FLORIDA
}

The effect of a variety of experimental variables on the latency of a pentobarbital-induced sleep response was studied in the rat. Diumal cycle, white noise, and sleep deprivation were found to exert significant influences while bright light, social facilitation, and food deprivation did not. In two studies which measured sleep length, diumal cycle but not food deprivation was found to exert a significant effect. A low correlation between sleep latency and length supports the assumption that these are independent responses.

Recent studies have demonstrated significant relationships between characteristics of a sleep response induced by pentobarbital and a number of experimental variables. Davis (1962) demonstrated the influence of day-night periodicity, temperature, and grouped vs. isolated housing conditions on the length of such a response in mice. Shagass (1960) has related barbituate sedation threshold to personality variables. An earlier report by Levitt \& Webb (1964) noted the effect of successive injections of pentobarbital on both the latency and length of an induced sleep response in rats.

The studies reported here are part of a general program concerned with the antecedent conditions affecting occurrence of the sleep response. Concurrently these experiments provide relevant pharmacological data on variables interacting with drug action. Method

The Ss were adult male Long-Evans rats. Age ranged from 140 to 190 days but was held constant within each experiment. The Ss had free access to food and water except during observation periods, and in Experiment VI which examined the effects of food deprivation. With the exception of Experiment VII, Ss were housed and tested individually in $10 \times 7 \times 7$ in. cages.

The control condition was identical in all experiments. The room was moderately lighted by $60 \mathrm{w}$ bulbs in the ceiling, sound dampened, and maintained at about $70^{\circ} \mathrm{F}$. The lights were on $12 \mathrm{hr}$. per day from $4 \mathrm{a} . \mathrm{m}$. to 4 p.m. Experimental sessions were in the morning between 9 and 11 a.m. The $\mathrm{S}$ was removed from its cage, received an intraperitoneal (IP) injection and was returned to the cage.

Sleep latency and length were determined by observation. The $\mathbf{S}$ was considered asleep when it was lying prone with its head resting on the cage floor. Sleep length was measured from the onset of the sleep response. The $\mathrm{S}$ was considered awake when its head was raised from the cage floor and this waking state was maintained for 3 consecutive min. Preliminary studies indicated a good correlation between these behavioral conditions and EEG indications of the onset of sleeping and waking. Although sleep latency was determined in all studies, sleep length measures were made only in Experiments II and VI. Experiment I was concerned with dosage level. In all other experiments the dose was $20 \mathrm{mg} / \mathrm{kgm}$ of pentobarbital sodium injected IP.

Experiment I (dosage level). Nine Ss received each of three doses: 5,10 , and $20 \mathrm{mg} / \mathrm{kgm}$ IP and sleep latency was measured. Observations were discontinued if $\mathrm{S}$ did not sleep within $30 \mathrm{~min}$. Experiments were at 48-hr. intervals.

Experiment II (diurnal cycle). Seven Ss each received 14 test sessions: seven at $10 \mathrm{a} . \mathrm{m}$. (control) and seven at 10 p.m. (experimental) in an alternated sequence. Tests were at $36-\mathrm{hr}$. intervals to permit alternation of morning and evening trials. A $40 \mathrm{w}$ bulb located about $25 \mathrm{ft}$. from the cages was on during night testing to permit observation of the sleep response.

Experiment III (sleep deprivation). Ten Ss were tested following 24-hr. sleep deprivation produced by a slowly revolving treadmill partially immersed in water (Webb \& Agnew, 1962). Five Ss received a control injection $24 \mathrm{hr}$. before being placed on the wheel and five received a control injection $48 \mathrm{hr}$. after removal from the wheel.

Experiment IV (lighting). Six Ss were exposed to each of three conditions: control, intermittent light, and constant light. The sequence was repeated six times for each $\mathrm{S}$. The light condition was produced by a $150 \mathrm{w}$ spotlight placed $10 \mathrm{in}$. above the cage. In the intermittent condition the light went on and off at 1-sec. intervals. Experiments were at 48-hr. intervals.

Experiment V (noise). Six Ss received each of three conditions: control, continuous noise, and intermittent noise. The sequence was repeated six times for each $\mathrm{S}$. The noise was a midrange $85 \mathrm{~dB}$ sound emitted into the cage from two sources 8 in. apart on opposite walls of the test cage. The intermittent noise went on and off at 1-sec. intervals. Experimental sessions were at 48-hr. intervals.

Experiment VI (food deprivation). This experiment was designed to determine the effect of an irrelevant drive. Two levels of food deprivation were used (24 and $48 \mathrm{hr}$.) as well as a no-deprivation control condition. Eight Ss were tested under each of the three conditions twice. The trials were at $96-\mathrm{hr}$. intervals allowing recuperation (as defined by body weight) between conditions. The mean weight of these Ss was 
Table 1. Mean Sleep Latencies and Percentage Change.

\begin{tabular}{llll} 
Experiment & \multicolumn{2}{c}{ Control Experimental Percentage Change } \\
\hline II Ciurnal Cycle & 311 sec. & 338 sec. & $+10 \%$ \\
III Sleep Deprivation & 316 & 223 & -22 \\
IV Control & 259 & & \\
$\quad \begin{array}{l}\text { Constant Light } \\
\text { Intermittent Light }\end{array}$ & & 289 & +13 \\
V Control & 313 & 285 & +12 \\
$\quad \begin{array}{l}\text { Constant Noise } \\
\text { Intermittent Noise }\end{array}$ & & 352 & +14 \\
VI Control & 392 & +27 \\
$\begin{array}{l}\text { 24-hr. Food Deprivation } \\
\text { 48-hr. Food Deprivation }\end{array}$ & 298 & +11 \\
VII Social Facilitation & 233 & 289 & +7 \\
\hline
\end{tabular}

$360 \mathrm{gm}$ before the experiment and $365 \mathrm{gm}$ after the experiment was concluded. Twenty-four and $48 \mathrm{hr}$. food deprivation produced 12 and 16 percent weight losses. The drug dose was based on the Ss' weight at the time of each injection.

Experiment VII (social facilitation). The presence of a waking rat in the observation cage during testing produced the experimental condition. Ten Ss received each of the conditions twice (social and isolated control). Tests were at $48-\mathrm{hr}$. intervals.

\section{Results}

Experiment I (dosage level). No S slept within $30 \mathrm{~min}$. at $5 \mathrm{mg} / \mathrm{kgm}$. At $10 \mathrm{mg} / \mathrm{kgm}$, latencies ranged from $7 \mathrm{~min}$. to assigned values of $30 \mathrm{~min}$. at which time observations were discontinued. At $20 \mathrm{mg} / \mathrm{kgm}$, the range of sleep latencies for the nine Ss was 200-300 sec. Since our goal of obtaining latencies in a sufficiently restricted range for use as a reliable dependent variable seemed to be realized at the $20 \mathrm{mg} / \mathrm{kgm}$ dosage, this experiment was terminated.

Sleep latencies. An examination of the data showed that the control group latencies of the various experiments differed considerably (Table 1). An analysis of variance confirmed the presence of differences among the control conditions $(p<.001)$, therefore, each of the experiments (II-VII) was analyzed separately. Three of the six treatments (diurnal cycle, $p<.01$; sleep deprivation, $\mathrm{p}<.05$; and noise, $\mathrm{p}<.05$ ) produced a significant change in latency.

In order to consider the relative effect of the various treatments across experiments, each S's score was converted to a percentage of his control condition latency. An analysis of variance of these ratios showed a significant difference between treatments $(p<.001)$.
Duncan's new multiple range test was applied to the ratio data. Sleep deprivation latencies were shorter, and intermittent sound latencies longer, than the other treatment latencies $(p<.05)$.

Sleep length. For Experiments II (diurnal cycle) and VI (food deprivation), sleep length measures were taken. The diurnal cycle effect $(p<.05)$, but not food deprivation, altered sleep length. Mean sleep lengths in the diurnal cycle study were $45 \mathrm{~min}$. and $36 \mathrm{~min}$. respectively during the morning and night trials.

\section{Discussion}

In regard to the latency of a pentobarbital-induced sleep response, three experimental variables were significant in their effect: diurnal cycle, noise (in particular, intermittent noise), and sleep deprivation. It may be possible to ascribe the sound effect to an orienting reflex since it was noted that animals attended to the speakers with investigatory responses. A common denominator of the variables which significantly altered latency may be a change in the level of behavioral arousal or drive. However, it is interesting to note that two levels of food deprivation, a drive irrelevant to the sleep response, did not alter sleep length or latency. This finding adds some strength to the conclusion that the decrease in sleep latency produced by sleep deprivation was specific to the sleep drive and not due to a nonspecific change in drive level.

In order to consider the relationship between sleep latency and length, latency and length scores were correlated for 21 Ss on which control values for both measures were available. The resulting correlation was -.15. It would appear that the two techniques are measuring independent sources of variance.

\section{References}

Davis, W. M. Day-night periodicity in pentobarbital response of mice and the influence of socio-psychological conditions. $E x^{-}$ perientia, 1962, 18, 235-237.

Levitt, R. A., \& Webb, W. B. The effect of pentobarbital sodium on sleep latency and length. Nature, 1964, 204, 605-606.

Shagass, C. Drug thresholds as indicators of personality and affect. In L. Uhr and J. C. Miller (Eds.), Drugs and behavior. New York: Wiley, 1960.

Webb, W. B., \& Agnew, H. W., Jr. Sleep deprivation, age, and exhaustion time in the rat. Science, 1962, 136, 1122.

\section{Note}

1. This research was supported in part by a PHS grant to WBW and by a NASA Predoctoral Fellowship to RAL. The authors wish to express their appreciation to $H$. S. Pennypacker for reading the manuscript and for his helpful comments. 